Celal Bayar University Journal of Science

\title{
Synthesis and catalytic activities of bimetallic Ru (II) arene complexes bearing bis-benzimidazoles
}

\author{
Salih Günnaz* \\ Ege University, Department of Chemistry, 35100, Bornova, Izmir, TURKEY \\ *salih.gunnaz@ege.edu.tr
}

Received: 11 November 2019

Accepted: 12 December 2019

DOI: $10.18466 /$ cbayarfbe. 632188

\begin{abstract}
In this study, bis-benzimidazole ligands (1a-d) were synthesized using linker groups and they were evaluated as catalyst generated in situ from $\left[\mathrm{RuCl}_{2}(p \text {-cymene })\right]_{2}$ for transfer hydrogenation $(\mathrm{TH})$ of acetophenone. The bimetallic $\mathrm{Ru}$ (II) arene complex (2b) synthesized from ligand $\mathbf{1 b}$ which showed the best activity among the ligands in the catalytic TH reaction. The obtained ligands and $\mathbf{2} \mathbf{b}$ complex were characterized by ${ }^{1} \mathrm{H}$ - and ${ }^{13} \mathrm{C}-\mathrm{NMR}$, elemental analysis and IR spectroscopy. The catalytic activities of complexes having different chain lengths and $\mathrm{Y}\left(\mathrm{CH}_{3}\right.$ or $\left.\mathrm{H}\right)$ groups were compared. The highest conversion $(99 \%)$ was obtained with $\mathbf{2 b}$.
\end{abstract}

Keywords: Bis-benzimidazole; ruthenium; transfer hydrogenation.

\section{Introduction}

Benzimidazole is a heterocyclic aromatic organic compound consisting of fusion of benzene and imidazole. Transition metal complexes of benzimidazole ligands are frequently used because of their unique properties such as biological activity, high thermal stability and good catalytic performance (1-4).

The benzimidazole can be easily modified due to its pyrrole-type nitrogen. For example, they are alkylated with alkyl halides so as to give 1-alkylbenzimidazoles. Bis-benzimidazoles can also be synthesized when 1,4and / or 1,6-dialkyl halides are used as linker groups (515). Reduction of carbonyl bonds by catalytic transfer hydrogenation using $\mathrm{Ru}$ (II) catalyst is of interest due to its simplicity and safety (16-19). Hydrogenation of substrates using a source of $\mathrm{H}_{2}$ in combination with the catalyst is a highly economical and preferred method.

In this study, primarily a series of bis-benzimidazole ligands were synthesized (1a-d) and the catalytic performance of these obtained ligands $\left[\mathrm{RuCl}_{2}(p\right.$ cymene) $]_{2}$ for transfer hydrogenation of acetophenone in situ conditions was investigated. The catalytic activity of the $\mathrm{Ru}$ (II) (2b) complex synthesized from the ligand (1b) showing the highest activity was compared with the in situ test results. The structures of the synthesized ligands and complexes were characterized using different spectroscopic techniques.

\section{Materials and Methods}

Reactions involving air-sensitive components were carried out under argon atmosphere conditions and standard Schlenk techniques of vacuum-line systems were employed during the experiments. For this reason, the glass containers used in the reaction were heated under vacuum, moisture and oxygen were removed and then filled with dry argon gas before the reaction. The solvents and reagents were dried before use and purified in an inert atmosphere.

${ }^{1} \mathrm{H}-(400 \mathrm{MHz})$ and ${ }^{13} \mathrm{C}-\mathrm{NMR}(100 \mathrm{MHz})$ spectra were recorded by Varian AS 400 NMR spectrometer, the chemical shift values $(\delta)$ of the compounds in ppm and the coupling constants $(\mathrm{J})$ were given in Hertz. In NMR measurements, $\mathrm{CDCl}_{3}$ and DMSO- $\mathrm{d}_{6}$ were used as the solvents and TMS was used as the internal standard. ${ }^{1} \mathrm{H}$ NMR signal cleavages were abbreviated as $s=$ singlet, $\mathrm{d}=$ doublet, $\mathrm{t}=$ triplet, $\mathrm{q}=$ quartet, $\mathrm{m}=$ multiplet. FTIR measurements were taken in the Perkin Elmer Spectrum 100 spectrophotometer on the ATR unit in the range of $4000-400 \mathrm{~cm}^{-1}$. Elemental analysis was recorded with Perkin Elmer 2400 element analyzer.

\subsection{Synthesis and Characterization of Ligands (1a- d, 2a-d)}

1a-d were synthesized by $\mathrm{N}$-alkylation using 1,4- and/or 1,6-dialkylhalides in the alkaline solution (Figure 1). 
The obtained structures were characterized by elemental analysis, NMR and IR techniques. All spectra are consistent with the proposed structures.

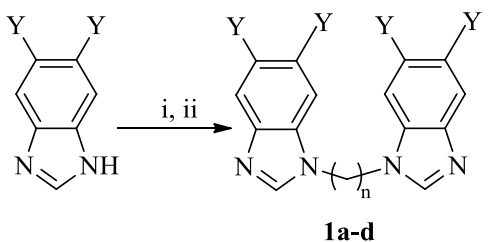
1a: $\mathrm{n}=4 ; \mathrm{Y}=\mathrm{H}$
1b: $\mathrm{n}=4 ; \mathrm{Y}=\mathrm{CH}_{3}$
1c: $\mathrm{n}=6 ; \mathrm{Y}=\mathrm{H}$
1d: $\mathrm{n}=6 ; \mathrm{Y}=\mathrm{CH}_{3}$

Reaction conditions: i) $\mathrm{KOH}$ ( 1 eq.), Acetone, $56^{\circ} \mathrm{C}, 1 \mathrm{~h}$.

ii) Alkyl halide (0.5 eq.), $6 \mathrm{~h}$.

Figure 1. Synthesis of bis-benzimidazole ligands (1ad).

\subsection{General Procedure for the Synthesis of (1a-d)}

Benzimidazole (236 mg; $2 \mathrm{mmol}$ ) or 5,6-dimethyl benzimidazole (292 $\mathrm{mg} ; 2 \mathrm{mmol}$ ) in a Schlenk was dissolved in acetone in the presence of $\mathrm{KOH}(112 \mathrm{mg}$; 2 mmol) with heating under reflux for 1 hour. Subsequently, 1,4-dibromobutane ( $215 \mathrm{mg} ; 1 \mathrm{mmol})$ or 1,6-dichlorohexane (155 mg; $1 \mathrm{mmol})$ was added and refluxed for 6 hours. Then the solvent was removed in vacum, the residue was dissolved with dichloromethane $(5 \mathrm{~mL})$ and filtered. Diethyl ether $(10 \mathrm{~mL})$ was added to the solution. The crystals obtained were filtered and dried under vacuum.

\subsubsection{1,1'-butane-1,4-diylbis- $1 H$-benzimidazole (1a)}

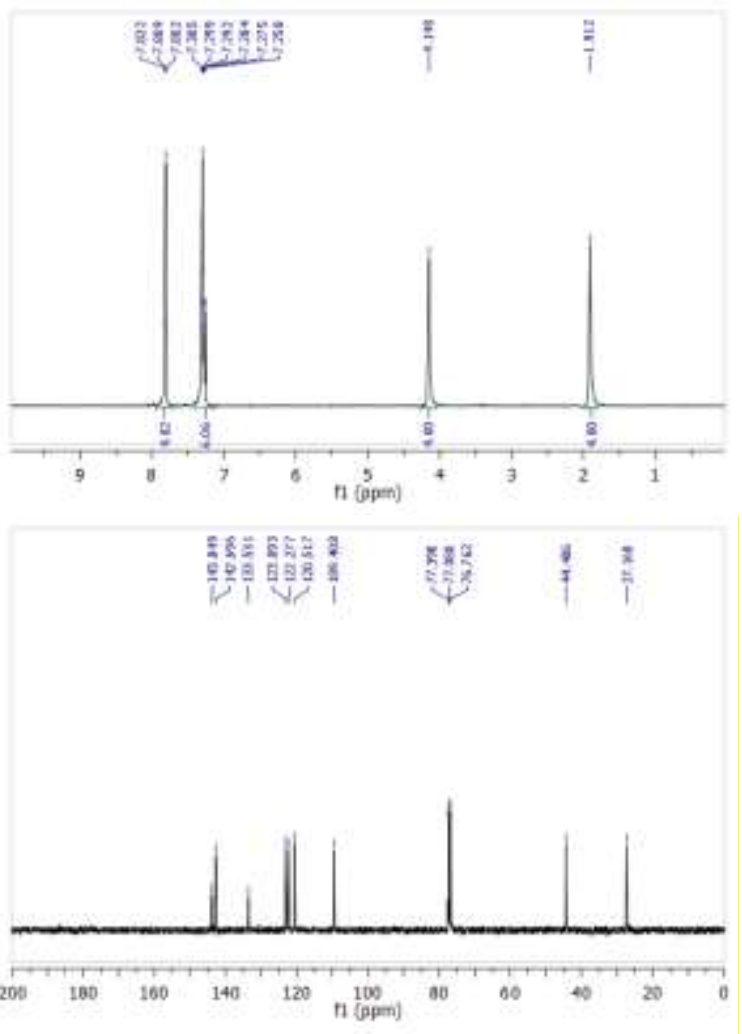

Figure 2. ${ }^{1} \mathrm{H}$ - and ${ }^{13} \mathrm{C}-\mathrm{NMR}$ spectra of $\mathbf{1 a}$. 1a: Yield: $88 \% .{ }^{1} \mathrm{H}-\mathrm{NMR}\left(400 \mathrm{MHz}, \mathrm{CDCl}_{3}, \mathrm{TMS}, 25\right.$ ${ }^{\circ} \mathrm{C}$, ppm): 1.91 (bs, 4H, $\mathrm{NCH}_{2} \mathrm{CH}_{2}$ ), 4.15 (bs, 4H, $\left.\mathrm{NCH}_{2}\right)$, 7.26-7.31 (m, 2H, NCHN, 4H, Benz-H) 7.807.82 (m, 4H, Benz- $H$ ). ${ }^{13} \mathrm{C}-\mathrm{NMR}\left(100 \mathrm{MHz}, \mathrm{CDCl}_{3}\right.$, TMS, $25{ }^{\circ} \mathrm{C}$, ppm): 27.2, 44.6, 109.4, 120.5, 122.2, 123.0, 133.5, 142.7, 143.8. Elemental analysis: calcd (\%) for $\mathrm{C}_{18} \mathrm{H}_{18} \mathrm{~N}_{4}(290,36) \mathrm{C} 74.46 ; \mathrm{H} 6.25 ; \mathrm{N} 19.30$. Found (\%): C 74.51; H 6.18; N 19.26. IR ( $\left.\mathrm{KBr} ; \mathrm{cm}^{-1}\right)$ : $1493\left(v_{\mathrm{C}=\mathrm{N}}\right)$.

\subsubsection{1,1'-butane-1,4-diylbis(5,6-dimethyl-1H- benzimidazole) (1b)}

1b: Yield: $86 \% .{ }^{1} \mathrm{H}-\mathrm{NMR}\left(400 \mathrm{MHz}, \mathrm{CDCl}_{3}\right.$, TMS, 25 ${ }^{\circ} \mathrm{C}, \mathrm{ppm}$ ): 1.85 (bs, 4H, $\left.\mathrm{NCH}_{2} \mathrm{CH}_{2}\right), 2.37$ ( s, $12 \mathrm{H}$, $4 \times \mathrm{XH}_{3}$ ), 4.08 (bs, 4H, $\mathrm{NCH}_{2}$ ), 7.05 (s, 2H, Benz- $H$ ), $7.55(\mathrm{~s}, 2 \mathrm{H}, \mathrm{NCHN}), 7.68(\mathrm{~s}, 2 \mathrm{H}, \mathrm{Benz}-H) .{ }^{13} \mathrm{C}-\mathrm{NMR}$ (100 MHz, $\mathrm{CDCl}_{3}$, TMS, $25{ }^{\circ} \mathrm{C}$, ppm): 20.2, 20.5, 27.0, 44.4, 109.6, 120.5, 131.1, 132.0, 132.2, 141.9, 142.5. Elemental analysis: calcd (\%) for $\mathrm{C}_{22} \mathrm{H}_{26} \mathrm{~N}_{4}$ (346): C, 76.27; H, 7.56; N, 16.17. Found (\%): C, 76.07; H, 7.76; $\mathrm{N}, 16.09$. IR $\left(\mathrm{KBr} ; \mathrm{cm}^{-1}\right): 1495\left(\mathrm{v}_{\mathrm{C}=\mathrm{N}}\right)$.

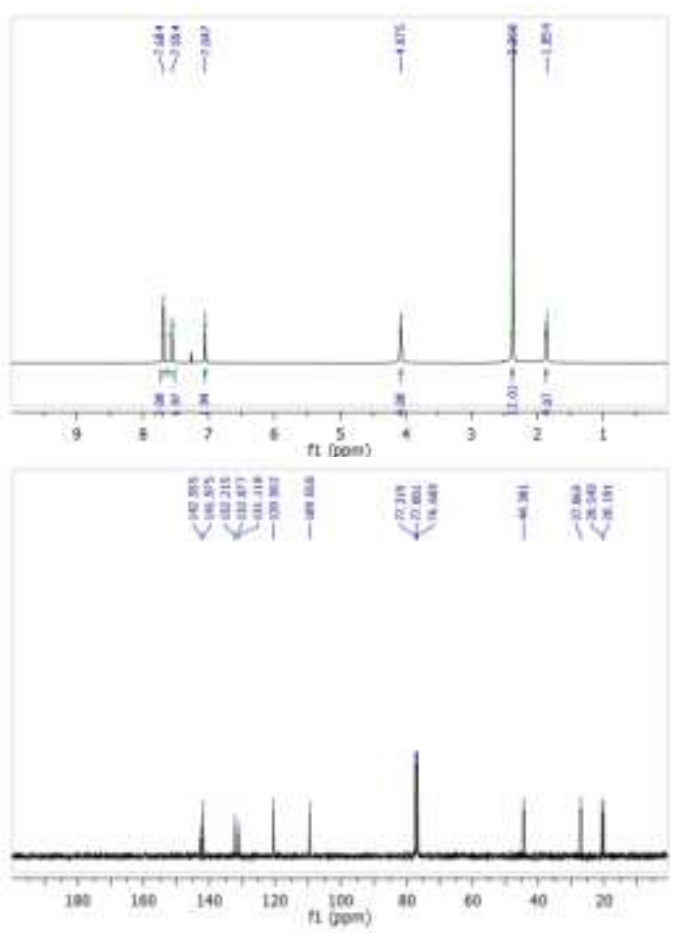

Figure 3. ${ }^{1} \mathrm{H}$ - and ${ }^{13} \mathrm{C}-\mathrm{NMR}$ spectra of $\mathbf{1 b}$.

2.2.3. 1,1'-hexane-1,6-diylbis-1H-benzimidazole (1c) 1c: Yield: $85 \% .{ }^{1} \mathrm{H}-\mathrm{NMR}\left(400 \mathrm{MHz}, \mathrm{CDCl}_{3}, \mathrm{TMS}, 25\right.$ ${ }^{\circ} \mathrm{C}$, ppm): 1,31-1.34 (m, 4H, $\left.\mathrm{NCH}_{2} \mathrm{CH}_{2} \mathrm{CH}_{2}\right), 1.83-1.86$ (bs, $4 \mathrm{H}, \mathrm{NCH}_{2} \mathrm{CH}_{2}$ ), $4.12\left(\mathrm{t}, 4 \mathrm{H}, J=7.0 \mathrm{~Hz}, \mathrm{NCH}_{2}\right.$ ), 7.26-7.35 (m, 2H, NCHN, 4H, Benz-H), 7.79-7.82 (m, $4 \mathrm{H}$, Benz- $H) .{ }^{13} \mathrm{C}-\mathrm{NMR}\left(100 \mathrm{MHz}, \mathrm{CDCl}_{3}, \mathrm{TMS}, 25\right.$ ${ }^{\circ} \mathrm{C}$, ppm): 26.3, 29.5, 44.8, 109.5, 120.4, 122.0, 122.8, 133.7, 142.8, 143.9. Elemental analysis: calcd (\%) for $\mathrm{C}_{20} \mathrm{H}_{22} \mathrm{~N}_{4}$ (318.42): C, 75.44; H, 6.96; N, 17.60. Found (\%): C, 75.49; H, 6.92; N, 17.66. IR $\left(\mathrm{KBr} ; \mathrm{cm}^{-1}\right): 1496$ $\left(v_{\mathrm{C}=\mathrm{N}}\right)$. 


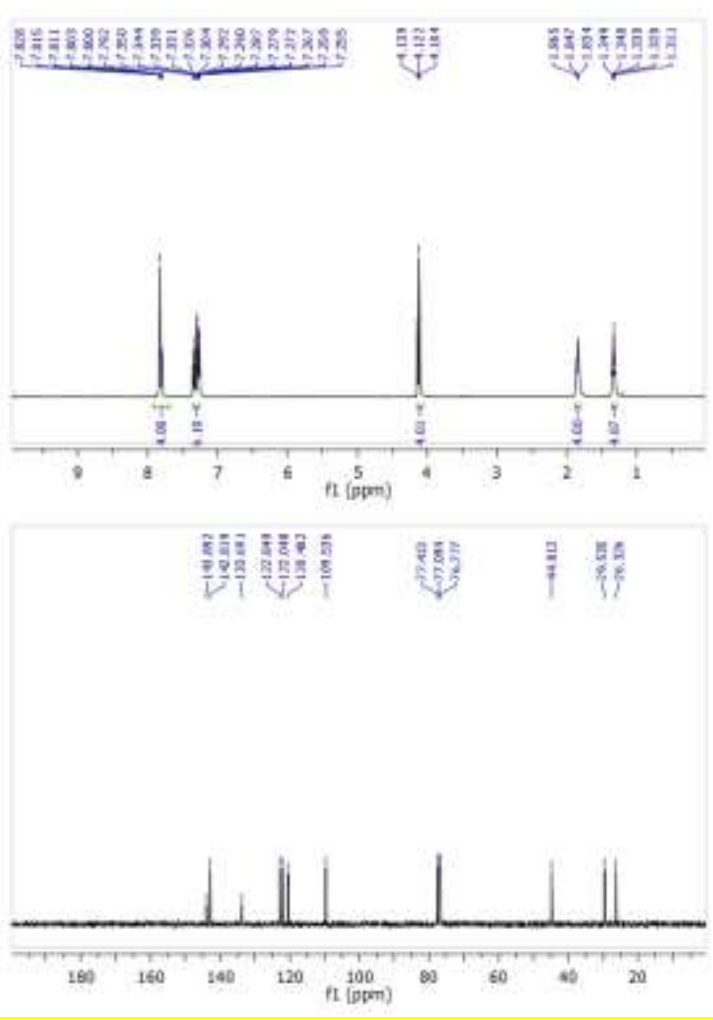

Figure 4. ${ }^{1} \mathrm{H}$ - and ${ }^{13} \mathrm{C}-\mathrm{NMR}$ spectra of $\mathbf{1 c}$.

\subsubsection{1,1'-hexane-1,6-diylbis(5,6-dimethyl-1H-} benzimidazole) (1d)

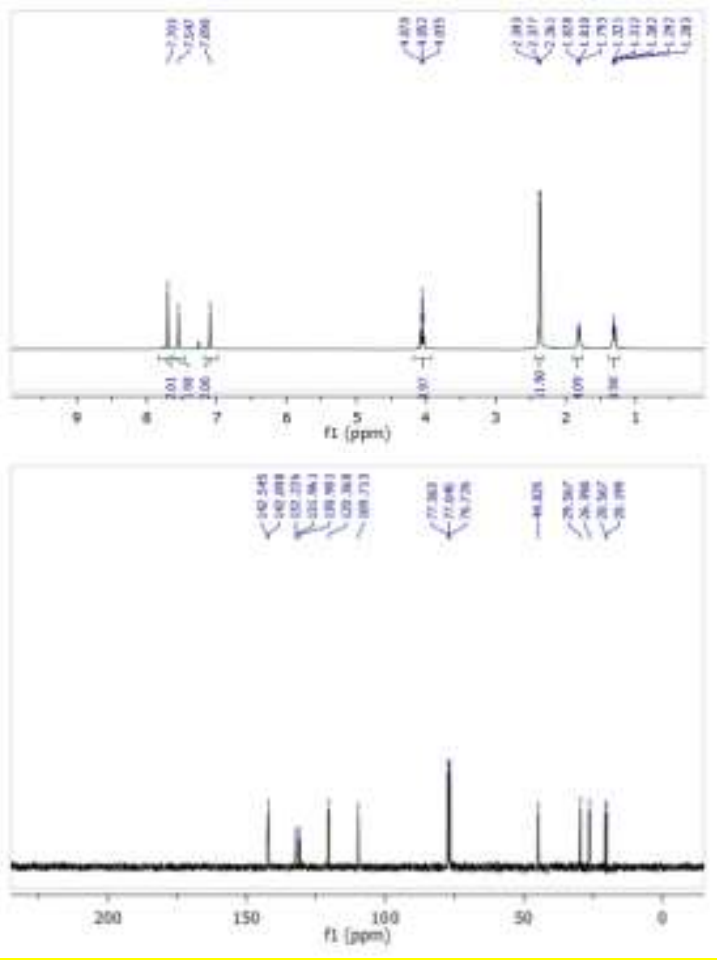

Figure 5. ${ }^{1} \mathrm{H}$ - and ${ }^{13} \mathrm{C}-\mathrm{NMR}$ spectra of $\mathbf{1 d}$. 1d: Yield: $81 \% .{ }^{1} \mathrm{H}$ NMR $\left(400 \mathrm{MHz}, \mathrm{CDCl}_{3}, \mathrm{TMS}, 25\right.$ ${ }^{\circ} \mathrm{C}$, ppm): $1,28-1.32$ (m, $4 \mathrm{H}, \mathrm{NCH}_{2} \mathrm{CH}_{2} \mathrm{CH}_{2}$ ), 1.79-1.82 (bs, $\left.4 \mathrm{H}, \mathrm{NCH}_{2} \mathrm{CH}_{2}\right), 2.36\left(\mathrm{~s}, 6 \mathrm{H}, 2 \mathrm{xCH}_{3}\right), 2.39(\mathrm{~s}, 6 \mathrm{H}$, $\left.2 \mathrm{xCH}_{3}\right), 4.05\left(\mathrm{t}, 4 \mathrm{H}, J=7.0 \mathrm{~Hz}, \mathrm{NCH}_{2}\right), 7.09(\mathrm{~s}, 2 \mathrm{H}$, Benz-H), 7.55 (s, 2H, NCHN), 7.70 (s, 2H, Benz- $H$ ). ${ }^{13} \mathrm{C}$ NMR $\left(100 \mathrm{MHz}, \mathrm{CDCl}_{3}, \mathrm{TMS}, 25{ }^{\circ} \mathrm{C}\right.$, ppm): 20.2 , 20.6, 26.4, 29.6, 44.8, 109.7, 120.4, 130.9, 131.9, 132.2, 142.0, 142.5. Elemental analysis: calcd (\%) for $\mathrm{C}_{24} \mathrm{H}_{30} \mathrm{~N}_{4}$ (374.52): C 76.97; $\mathrm{H}$ 8.07; $\mathrm{N}$ 14.96. Found (\%): C 76.91; H 8.13; N 14.91. IR $\left(\mathrm{KBr} ; \mathrm{cm}^{-1}\right): 1502$ $\left(v_{\mathrm{C}=\mathrm{N}}\right)$.

\subsubsection{1,1'-butane-1,4-diylbis(3-\{(dichloro)(p- cymene)ruthenium $\}-5,6$-dimethyl- benzimidazole) (2b)}

1b $(0.2 \mathrm{mmol})$ and $\left[\mathrm{RuCl}_{2}(p \text {-cymene })\right]_{2}(0.2 \mathrm{mmol})$ in dry dichloromethane $(5 \mathrm{~mL})$ were stirred at room temperature for 24 hours under Argon in a Schlenk. The solution was reduced in vacuo to a volume of $1 \mathrm{~mL}$ and precipitated with diethyl ether to give a solid. The dark yellow precipitate was filtered off and dried in vacuum.

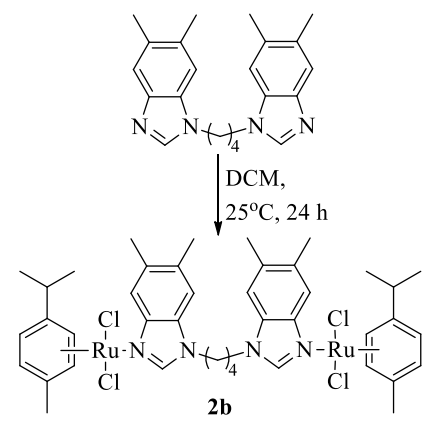

Figure 6. Synthesis of complex $\mathbf{2 b}$.

As the obtained complex did not have sufficient solubility in chloroform, NMR data of both $\mathbf{2 b}$ complex and $\mathbf{1 b}$ ligand were recorded using DMSO- $\mathrm{d}_{6}$.

2b: Yield: \%78. ${ }^{1} \mathrm{H}-\mathrm{NMR}\left(400 \mathrm{MHz}, \mathrm{DMSO}-\mathrm{d}_{6}\right.$, TMS, $\left.25{ }^{\circ} \mathrm{C}, \mathrm{ppm}\right)$ : TMS, $\left.25^{\circ} \mathrm{C}, \mathrm{ppm}\right): 1.17(\mathrm{~d}, 12 \mathrm{H}, J=6.4$ $\mathrm{Hz}$, p-cymene- $4 \mathrm{xCH}_{3}$ ), 1.90 (bs, $4 \mathrm{H}, \mathrm{NCH}_{2} \mathrm{CH}_{2}$ ), 2.07 (s, $6 \mathrm{H}$, p-cymene- $\left.2 \mathrm{xCH}_{3}\right), 2.36\left(\mathrm{~s}, 12 \mathrm{H}, 4 \mathrm{xCH}_{3}\right), 2.77$ $2.85(\mathrm{~m}, 2 \mathrm{H}, \mathrm{p}$-cymene- $2 \mathrm{xCH}), 4.46$ (bs, $4 \mathrm{H}, \mathrm{NCH}_{2}$ ), $5.77\left(\mathrm{dd}, 8 \mathrm{H}, J_{I}=17.2, J_{2}=6.4 \mathrm{~Hz}, \mathrm{p}\right.$-cymene- Ar- $H$ ), 7.58 (s, 2H, Benz-H), 7.72 (s, 2H, Benz-H), 9.49 (s, $2 \mathrm{H}, \mathrm{NC} H \mathrm{~N}) .{ }^{13} \mathrm{C}-\mathrm{NMR}\left(100 \mathrm{MHz}, \mathrm{DMSO}-\mathrm{d}_{6}, \mathrm{TMS}, 25\right.$ $\left.{ }^{\circ} \mathrm{C}, \mathrm{ppm}\right): 18.3,20.3,20.5,25.8,30.4,46.1,86.0,86.8$, $100.5,106.8,113.0,115.0,129.9,130.4,135.7,136.0$, 140.8. Elemental analysis: calcd (\%) for $\mathrm{C}_{42} \mathrm{H}_{54} \mathrm{Cl}_{4} \mathrm{~N}_{4} \mathrm{Ru}_{2}$ (958.86) Calcd (\%): C 52.61; H 5.68; N 5.84. Found (\%): C 52.47; H 5.81; N 5.86. IR (KBr; $\left.\mathrm{cm}^{-1}\right): 1512\left(v_{\mathrm{C}=\mathrm{N}}\right)$.

1b: ${ }^{1} \mathrm{H}-\mathrm{NMR}$ (400 MHz, DMSO-d 6 , TMS, $25^{\circ} \mathrm{C}$, ppm): 1.71 (bs, $\left.4 \mathrm{H}, \mathrm{NCH}_{2} \mathrm{CH}_{2}\right), 2.26$ ( s, $\left.12 \mathrm{H}, 4 \times \mathrm{xCH}_{3}\right), 4.17$ (bs, $\left.4 \mathrm{H}, \mathrm{NCH}_{2}\right), 7.27$ (s, 2H, Benz- $H$ ), 7.37 (s, $2 \mathrm{H}$, 
Benz- $H), 8.02$ (s, 2H, NCHN). ${ }^{13} \mathrm{C}$ NMR (100 MHz, DMSO-d ${ }_{6}$, TMS, $25{ }^{\circ} \mathrm{C}$, ppm): 20.3, 20.5, 27.1, 43.9, $110.7,119.9,130.2,131.3,132.7,142.5,143.5$.

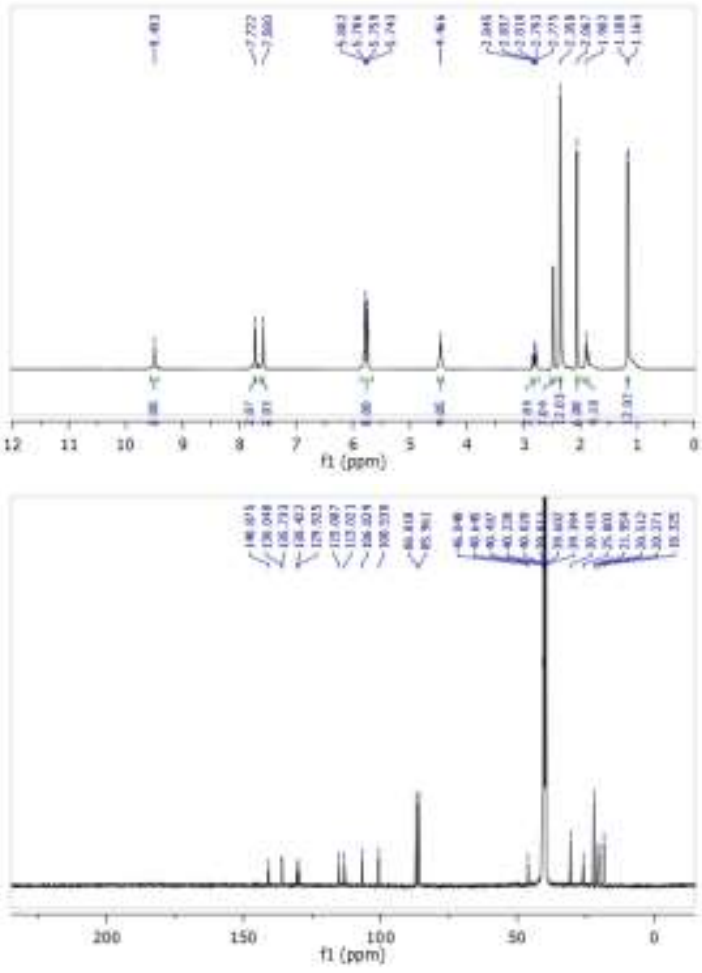

Figure 7. ${ }^{1} \mathrm{H}$ - and ${ }^{13} \mathrm{C}-\mathrm{NMR}$ spectra of $\mathbf{2 b}$.

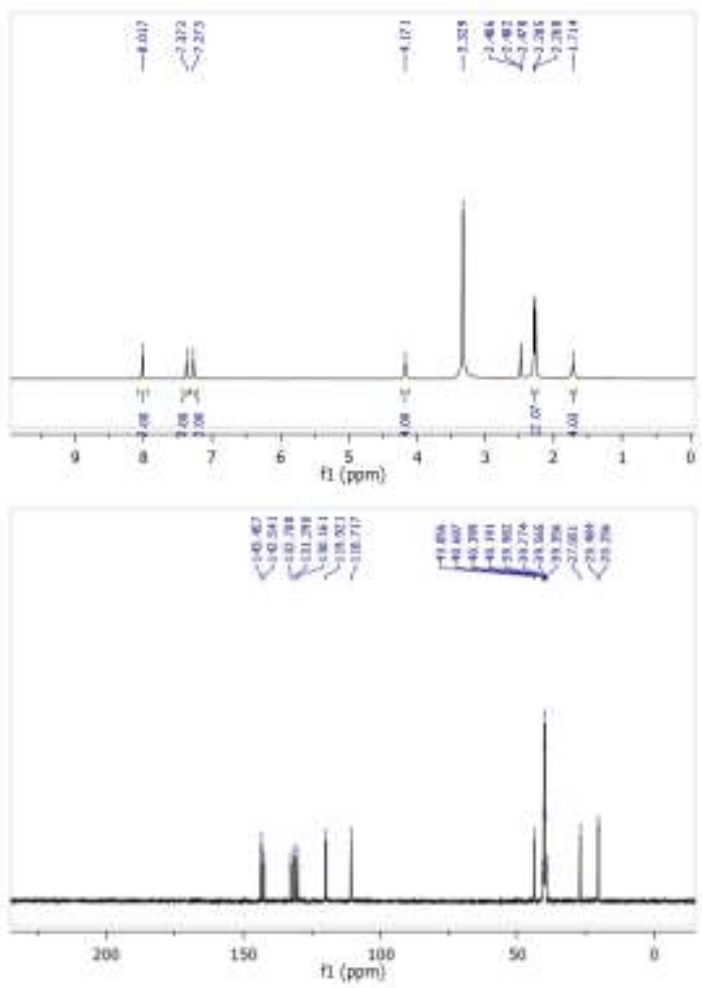

Figure 8. ${ }^{1} \mathrm{H}$ - and ${ }^{13} \mathrm{C}-\mathrm{NMR}$ spectra of $\mathbf{1 b}$ in DMSO- $\mathrm{d}_{6}$.

\subsubsection{General Procedure of Transfer Hydrogenation (TH) Reactions}

A mixture of acetophenone $(1 \mathrm{mmol})$, catalyst $\left(5 \times 10^{-3}\right.$ mmol, $1 \mathrm{~mol} \%)$, propan-2-ol $(2 \mathrm{~mL})$ and $\mathrm{KOH}(0.2$ $\mathrm{mmol}$ ) in a two-necked flask was mixed for 1 hour at 82 ${ }^{\circ} \mathrm{C}$. at reflux temperature. At the desired reaction times, the fractions were withdrawn from the reaction vessel. Yields were determined by ${ }^{1} \mathrm{H}-\mathrm{NMR}$.

\section{Results and Discussion}

Bis-benzimidazole ligands (1a-d) were obtained in high yields $(81-88 \%)$ by reacting benzimidazole or 5,6dimethylbenzimidazole with dialkyl halides in acetone at $56{ }^{\circ} \mathrm{C}$ for 6 hours. In the ${ }^{1} \mathrm{H}-\mathrm{NMR}$ spectrum of these ligands, characteristic singlet peaks of $\mathrm{N}=\mathrm{CH}-\mathrm{N}$ group were observed in the range of $\delta=7.28-7.55 \mathrm{ppm}$. In IR spectra, $\mathrm{C}=\mathrm{N}$ vibrations signal in the range of 1493$1502 \mathrm{~cm}^{-1}$. The spectroscopic values of the synthesized ligands were consistent with the proposed structures. Some spectroscopic data of complex $\mathbf{2 b}$ and ligand $\mathbf{1 b}$ are given in Table 1.

Table 1. Spectroscopic data of $\mathbf{1 b}$ and $\mathbf{2 b}$.

\begin{tabular}{ccc}
\hline & $\mathbf{N}=\mathbf{C H}-\mathbf{N}(\mathbf{p p m})$ & $\mathbf{I R}\left(\boldsymbol{v}_{\mathrm{C}=\mathrm{N}}\right)\left(\mathbf{c m}^{\mathbf{- 1}}\right)$ \\
\hline $\mathbf{1 b}$ & 8.02 & 1495 \\
$\mathbf{2 b}$ & 9.49 & 1512 \\
\hline
\end{tabular}

The catalytic performances of the catalysts formed by the interaction of the obtained ligands (1a-d) in the presence of $\left[\mathrm{RuCl}_{2}(p \text {-cymene })\right]_{2}$ in the transfer hydrogenation reaction of acetophenone were investigated. Since the optimum conditions the reaction temperature as $82{ }^{\circ} \mathrm{C}$ and the use of $\mathrm{KOH}$ as the base were determined in our previous studies [4], therefore in this study same conditions were employed. The obtained results are summarized in Table 2.

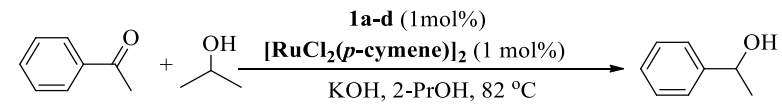

Table 2. Optimization table for TH of acetophenone ${ }^{\mathrm{a}}$.

\begin{tabular}{cccc}
\hline Entry & Catalyst & Ligand & Yield (\%) \\
\hline 1 & {$\left[\mathrm{RuCl}_{2}(p \text {-cymene })\right]_{2}$} & $\mathbf{1 a}$ & 50 \\
2 & {$\left[\mathrm{RuCl}_{2}(p \text {-cymene })\right]_{2}$} & $\mathbf{1 b}$ & $\mathbf{7 6}$ \\
3 & {$\left[\mathrm{RuCl}_{2}(p \text {-cymene })\right]_{2}$} & $\mathbf{1 c}$ & 45 \\
4 & {$\left[\mathrm{RuCl}_{2}(p \text {-cymene })\right]_{2}$} & $\mathbf{1 d}$ & 59 \\
5 & {$\left[\mathrm{RuCl}_{2}(p \text {-cymene })\right]_{2}$} & - & 29 \\
6 & - & $\mathbf{1 b}$ & 9 \\
7 & - & - & 7 \\
\hline
\end{tabular}

${ }^{\mathrm{a}}$ Reaction conditions: $\mathrm{KOH}(0.2 \mathrm{mmol}), 1 \mathrm{~h}$, Ketone (1 $\mathrm{mmol}), 2-\mathrm{PrOH}(2 \mathrm{~mL})$. 
In the study, the best result was obtained with ligand $\mathbf{1 b}$ (Table 2 , entry 2$)$. In the case where only $\left[\mathrm{RuCl}_{2}(p\right.$ cymene) $]_{2}$ was used as catalyst (Table 2 , entry 5), a conversion of $29 \%$ was achieved, whereas ligand $\mathbf{1 b}$ was used only without $\left[\mathrm{RuCl}_{2}(p \text {-cymene) }]_{2}\right.$ (Table 2, entry 6) a conversion of $9 \%$ was achieved. The preferred $\mathrm{KOH}$ as the base showed a $7 \%$ conversion after 1 hour (Table 2, entry 7). In view of these results, $\mathrm{Ru}$ (II) arene complex (2b) was synthesized in the next step using ligand $\mathbf{1 b}$ and the activity of the aromatic ketones in which the complex of $\mathbf{1 b}$ ligand as in situ $\mathbf{2 b}$ as the catalyst in the same reaction conditions was compared by means of the transfer hydrogenation reaction activities (Table 3 ).

\section{$1 \mathbf{b}(1 \mathrm{~mol} \%)$}

$$
\left[\operatorname{RuCl}_{2}(p \text {-cymene })\right]_{2}(1 \mathrm{~mol} \%)
$$

$$
\frac{2 b(1 \mathrm{~mol} \%)}{\mathrm{KOH}, 2-\mathrm{PrOH}, 82^{\circ} \mathrm{C}}
$$

Table 3. Comparison table of $\mathrm{TH}$ reaction.

Entry

\section{Conclusion}

In this study, the catalytic properties of the synthesized bis-benzimidazole ligands (1a-d) and $\mathbf{2 b}$ complex in the transfer hydrogenation reaction of acetophenone were investigated. In the in situ study, the highest results were obtained when 1b was used with $76 \%$ yield in 1 hour. The bimetallic $\mathbf{2 b}$ complex synthesized using this ligand yielded $93 \%$ yield under the same reaction conditions. The results were compared in cases where the $\mathbf{1 b}$ ligand in situ and $\mathbf{2 b}$ complex were used as catalysts in the transfer hydrogenation reaction using different ketones. Catalytic activity varies depending on the groups in the phenyl ring of acetophenone. In the presence of electron attractive groups it exhibited an increment. The best result was obtained using 4-chloro and 4-bromo acetophenone for a 1 hour reaction time, and when $\mathbf{2 b}$ was used as a catalyst, a yield of $99 \%$ was achieved.

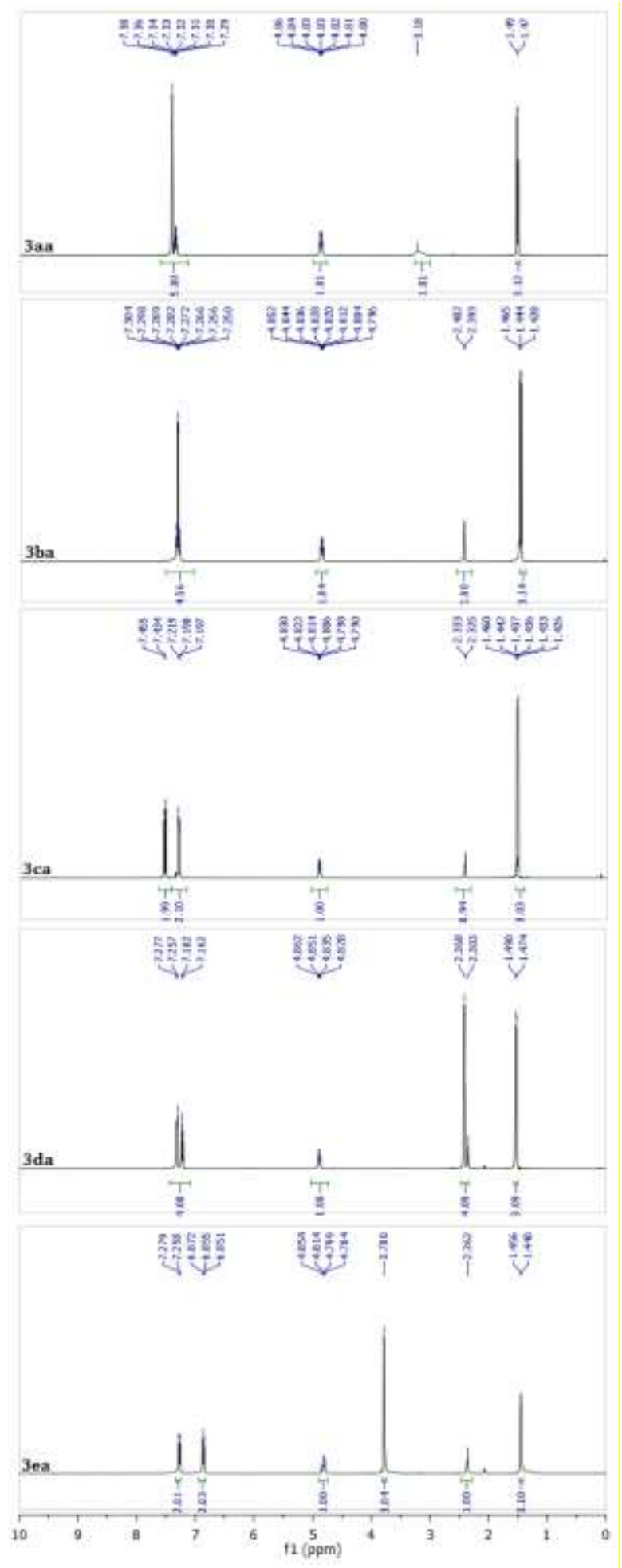

Figure 9. ${ }^{1} \mathrm{H}-\mathrm{NMR}$ spectra of the catalytic products

\section{Ethics}

There are no ethical issues after the publication of this manuscript. 
Celal Bayar University Journal of Science

Volume 15, Issue 4, 2019 p 351-356

Doi: $10.18466 /$ cbayarfbe.632188

\section{References}

1. Günnaz, S, Özdemir, N, Dayan, S, Dayan, O, Çetinkaya, B, 2011 Synthesis of Ruthenium(II) Complexes Containing Tridentate Triamine $\left({ }^{N} \bar{N} N^{\prime}\right)$ and Bidentate Diamine Ligands $\left(\mathrm{NN}^{\prime}\right)$ : as Catalysts for Transfer Hydrogenation of Ketones, Organometallics, 30(15): 4165-4173.

2. Haneda, S, Adachi, Y, Hayashi, M. 2009. Copper(I)-2-(2'pyridyl)benzimidazole catalyzed $\mathrm{N}$-arylation of indoles, Tetrahedron, 65(50): 10459-10462.

3. Haneda, S, Gan, Z, Eda, K, Hayashi, M. 2007. Ligand Effects of 2-(2-Pyridyl)benzazole-Pd Complexes on the X-ray Crystallographic Structures, ${ }^{1} \mathrm{H}$ NMR Spectra, and Catalytic Activities in Mizoroki-Heck Reactions, Organometallics, 26(26): 6551-6555.

4. Done, M, C, Ruther, T, Cavell, K, J, Kilner, M, Peacock, E. J, Braussaud, N, Skelton, B, W, White, A, J. 2000. Novel cationic and neutral $\mathrm{Pd}(\mathrm{II})$ complexes bearing imidazole based chelate ligands: synthesis, structural characterisation and catalytic behaviour, J. Organomet. Chem., 607(1): 78-92.

5. Zhao, X, Liu, D, Li, Y, Cui, G. 2018. Two 3D cadmium (II) coordination polymers modulated by flexible bis(benzimidazole) ligands displaying high photocatalytic activities for degradation of methylene blue and methyl orange, Polyhedron, 156(1): 200207.

6. Aksenov, A, V, Smirnov, A, N, Aksenov N, A, Bijieva, A, S Aksenova, I, V, Rubin, M. 2015. Benzimidazoles and benzoxazoles via the nucleophilic addition of anilines to nitroalkanes, Org. Biomol. Chem., 13(14): 4289-4295.

7. Zhang, D, Jiang, X, Yang, H, Martinez, A, Feng, M, Donga, Z, Gao, G. 2013. Acridine-based macrocyclic fluorescent sensors: self-assembly behavior characterized by crystal structures and a

15. Shi, Z, Thummel, R, P. 1995. Bridged dibenzimidazolinylidenes as new derivatives of tetraaminoethylene, Tetrahedron Lett., 36(16): 2741-2744.

16. Dayan, O, Özdemir, N, Şerbetci, Z, Dinçer, M, Çetinkaya, B, Büyükgüngör, O. 2012. Synthesis and catalytic activity of ruthenium(II) complexes containing pyridine-based tridentate triamines (NNN) and pyridine carboxylate ligands (NO), Inorg. Chim. Acta, 392(1): 246-253. tunable bathochromic-shift in emission induced by $\mathrm{H}_{2} \mathrm{PO} 4^{-}$via adjusting the ring size and rigidity, Org. Biomol. Chem., 11(20): 3375-3381.

8. Liu, Q, X, Wei, Q, Zhao, X, J, Wang, H, Li, S, J, Wang, X, G. 2013. Cobalt(II), copper(II), zinc(II) and cadmium(II) complexes based on dibenzimidazolyl bidentate ligands with alkanyl linkers: crystal structure, weak interactions and conformations, Dalton Trans., 42(16): 5902-5915.

9. Iaroshenko, V, O, Ostrovskyi, D, Miliutina, M, Maalik, A, Villinger, A, Tolmachev, A, Volochnyuk, D, M, Langer, P. 2012. Design and Synthesis of Polycyclic Imidazole-Containing $\mathrm{N}$ Heterocycles based on $\mathrm{C}-\mathrm{H}$ Activation/Cyclization Reactions, Adv. Synth. Catal., 354(13): 2495-2503.

10. Kucukbay, H, Yilmaz, U, Sireci, N, Onganer, A, N. 2011. Synthesis and antimicrobial activities of some bridged bisbenzimidazole derivatives, Turk. J. Chem., 35(4): 561-571.

11. Wang, D, E, Deng, K, J, Lv, K, L, Wang, C, G, Wen, L, L, Li, D, F. 2009. Structures, photoluminescence and photocatalytic properties of three new metal-organic frameworks based on nonrigid long bridges, CrystEngComm, 11(7): 1442-1450.

12. Wong, W, W, H, Vickers, M, S, Cowley, A, R, Paul, R, L, Beer, $\mathrm{P}$, D. 2005. Tetrakis(imidazolium) macrocyclic receptors for anion binding, Org. Biomol. Chem., 3(23): 4201-4208.

13. Ma, J, F, Liu, J, F, Liu, Y, C, Xing, Y, Jia, H, Q, Lin, Y, H. 2000. Two new coordination polymers of $\mathrm{Co}$ (II) with $1,1^{\prime}-(1,4-$ butanediyl)bis(benzimidazole), New J. Chem., 24(10): 759-763.

14. Shi, Z, Thummel, R, P. 1995. N,N'-Bridged Derivatives of 2,2'Bibenzimidazole, J. Org. Chem., 60(18): 5935-5945.

17. Noyori, R, Hashiguchi, S. 1997. Asymmetric Transfer Hydrogenation Catalyzed by Chiral Ruthenium Complexes, Acc. Chem. Res., 30(2): 97-102.

18. Gao, J, X, Ikariya, T, Noyori, R. 1996. A Ruthenium(II) Complex with a C2-Symmetric Diphosphine/Diamine Tetradentate Ligand for Asymmetric Transfer Hydrogenation of Aromatic Ketones, Organometallics, 15(4): 1087-1089. 